\title{
非弁膜症性心房細動における抗凝固療法のガイドライン改訂
}

篠原徹二, 高橋尚彦*

\section{Revised guidelines for anticoagulant therapy in patients with non-valvular atrial fibrillation}

Tetsuji SHINOHARA, Naohiko TAKAHASHI

要約：心房細動患者に対する抗凝固療法に扔いて, (1)塞栓症のリスク評価, (2)周術期の抗凝固療法, (3)虚血性 心疾患を合併した心房細動患者に対する抗血栓療法, (4)出血時の対応に関するガイドラインの追記・変更が行 われた，(1)では，生体弁患者は「非弁膜症性」として扱われ，一般的な非弁膜症性心房細動患者に対するワル ファリンは年齢に関わらず INR1.6〜2.6が推奨となった，(2)では，手技の出血リスクに応じて抗凝固薬の休薬 は不要, 可能なら避ける, 休薬する, が明記された. (3)では, 冠動脈ステント留置 2 週以降は, アスピリンを 中止して抗凝固薬と P 2 Y 12 受容体拮抗薬との 2 剬併用療法を標準治療として行い, 慢性期（1 年以降）では抗 凝固薬の単剤投与を標準治療として行うこととなった。 (4)では, 直接経口抗凝固薬 (direct oral anticoagulants: DOAC) 内服中の場合, 軽度では「経過観察, DOAC 1 回もしくは 1 日分の休薬」, 中等度から重度では「休 薬, 活性炭投与, 止血, 輸液, 十分な降圧, 中和」を適宜行うとされた.

Key words: Anticoagulation therapy, Atrial fibrillation, $\mathrm{CHADS}_{2}$ score, DOAC, Warfarin

\section{はじめに}

不整脈に対する薬物治療における最近の大きな变 化として 2 点が挙げられる。一つは, 不整脈に対す る薬物治療の目的（ゴール）の変化である。 カテー テルアブレーション治療の進歩による根治率の向上 と, 致死性不整脈に伴う突然死の予防治療における 植込2型除細動器の優位性が多くの大規模臨床試験 から報告されたことによって, 抗不整脈薬の使用目 的として, 不整脈の停止や発症予防ではなく, 患者 の予後や生活の質（QOL）の改善が重要視されるよ うになった. もう一つは, 直接経口抗凝固薬 (direct oral anticoagulants: DOAC）の普及によって，心房細 動に対する抗凝固療法が大きく変化したことである. このような現状を踏まえて，2020年 3 月に日本循環

*責任者連絡先：

大分大学医学部循環器内科 - 臨床検査診断学講座

$\overline{\mathbf{T}}$ 879-5593 大分県由布市挾間町医大ケ丘 1 丁目 1 番地

Tel: 097-586-6166, Fax: 097-586-6038

E-mail: takanao@oita-u.ac.jp
器学会／日本不整脈心電学会合同ガイドラインとし て,「2020年改訂版不整脈薬物治療ガイドライン」 が発表された ${ }^{1)}$ 。心房細動に対する抗凝固療法に関 しては, 「心房細動治療（薬物）ガイドライン（2013 年改訂版) 」) 以来の改訂であり，この約 7 年の期間 に発表されたエビデンスを加えて, (1)塞栓症のリス ク評価, (2)周術期の抗凝固療法, (3)虚血性心疾患を 合併した心房細動患者に対する抗血栓療法, (4)出血 時の対応において追記や変更が行われた（表1). 本 稿では, 非弁膜症性心房細動に対する抗凝固療法の 変更点を中心に述べていく.

\section{1. 塞栓症のリスク評価における変更点}

\section{1）僧帽弁置換術の生体弁患者}

弁膜症性心房細動患者では, DOAC の有効性およ び安全性は証明されていないため, ワルファリンを 用いた抗凝固療法が必要である. 2013 年版ガイドラ インにおいては ${ }^{2)}$, ウシやブタを用いた生体弁を「弁 膜症性」として扱っていた。近年, 生体弁手術後の 
表 12020 年改訂版不整脈薬物治療ガイドラインにおける主な変更点

(1)塞栓症のリスク評価において

$\checkmark$ 僧帽弁置換術後患者のうち, 生体弁患者は「非弁膜症性」として扱われるようになった.

$\checkmark \mathrm{CHADS}_{2}$ スコア1点以上で全ての DOACが「推奨」となった.

$\checkmark$ 非弁膜症性心房細動患者に対するワルファリンは年齢に関わらずINR1.6〜2.6でコントロールする（血栓塞栓症の高 リスク患者は除く).

$\checkmark \mathrm{CHADS}_{2}$ スコア因子以外の考虑すべきその他リスクとして,「持続性・永続性心房細動」,「腎機能障害」,「低体重 $(\leqq 50 \mathrm{~kg})\rfloor$, 「左房径 $(>45 \mathrm{~mm}) 」$ が追加された.

(2)周術期の抗凝固療法に扔いて

$\checkmark$ 出血の低リスク手技では「抗凝固薬の休薬は不要」, 中リスク手技では「抗凝固薬休薬を可能なら避ける」, 高リス クでは「抗凝固薬を休薬する」が明記された.

$\checkmark$ ワルファリンおよびDOAC 休薬時のヘパリン置換は推奨クラス IIb, Minds 推奨グレードC2（科学的根拠がなく, 行 わないよう勧められる）とされた。

(3)虚血性心疾患を合併した心房細動患者に対する抗血栓療法において

$\checkmark$ 冠動脈ステント留置患者における周術期（2 週間以内）以降は, アスピリンを中止して抗凝固薬と P2Y12 受容体拮 抗薬との 2 剂併用療法を標準治療として行う.

$\checkmark$ 冠動脈ステント留置後慢性期（1 年以降）では抗凝固薬の単剂投与を標準治療として行う.

(4)出血時の対応において

$\checkmark$ DOAC 内服中の場合, 軽度では「経過観察, DOAC 1 回もしくは 1 日分の休薬」, 中等度から重度では「休薬, 活性 炭投与, 止血, 輸液, 十分な降圧, 中和」を適宜行う.

$\checkmark$ DOACの中和は, ダビガトランではイダルシズマブ, Xa 阻害薬では andexanet alfa (2020 年 6 月現在未承認), およ び全てのDOACに対してプロトロンビン複合体製剤／遺伝子組換え第 VII 因子製剤（いずれも保険適用外）を用いる.

心房細動患者を対象とした DOAC の使用成績が複数 報告された ${ }^{3,4)}$. いずれも少数例の報告ではあるが, 血栓症予防効果についてはDOAC とワルファリンは 同等であった．このことを踏まえて，今回のガイド ラインに扔いて生体弁は「非弁膜症性」扱いになっ た。その結果, 僧帽弁狭窄症および機械弁置換術後 のみが「弁膜症性」扱いとなり, それ以外はすべて 「非弁膜症性心房細動」として差し支えないことに なった。

2） $\mathrm{CHADS}_{2}$ スコア 1 点以上で全ての DOAC が「推奨」 欧米では, 心原性塞栓症のリスク評価として $\mathrm{CHA}_{2} \mathrm{DS}_{2}-\mathrm{VASc}$ スコアが用いられている. 今回のガ イドライン改訂においては, 様々なディスカッショ ンの結果, 前回同様, $\mathrm{CHADS}_{2}$ スコアがリスク評価 として用いられることになった。この主な理由は, $\mathrm{CHADS}_{2}$ スコアは $\mathrm{CHA}_{2} \mathrm{DS}_{2}-\mathrm{VASc}$ スコアと比較して 簡便であること，および本邦で実施された代表的な
3 つの心房細動レジストリー研究（J-RHYTHM Registry, Fushimi AF Registry, Shinken Database) の 統合解析 ${ }^{5)}$ において, $\mathrm{CHA}_{2} \mathrm{DS}_{2}$-VASc スコアで追加 される「年齢 $(65 \sim 74$ 歳), 血管疾患, 女性」は有 意な危険因子ではなかったためである。ちなみに CHADS 2 スコアは, (1)心不全, (2)高血圧, (3)年齢 ( 75 歳), (4)糖尿病, (5)脳卒中または一過性脳虚血発 作（transient ischemic attack: TIA）の既往（各 1 点, 脳卒中/TIA は2 点）から構成されている（表 2)。そ して，スコア 0 点を低リスク，1点を中等度リスク， 2 点以上を高リスクとしている。 2013 年版ガイドラ インでは, $\mathrm{CHADS}_{2}$ スコア 1 点（中等度リスク）の 患者に対する抗凝固療法においてリバーロキサバン とエドキサバンはエビデンス不足のために「考慮可」 であった. 今回改訂されたガイドラインでは他の DOAC と同様に「推奨」となり, $\mathrm{CHADS}_{2}$ スコア 1 点以上ですべての DOACが「推奨」となった，表 3 


\begin{tabular}{|c|c|c|c|}
\hline \multirow[b]{2}{*}{$\mathrm{C}$} & \multicolumn{2}{|c|}{ 危険因子 } & \multirow{2}{*}{$\frac{\text { スコア }}{1}$} \\
\hline & Congestive heart failure & 心不全 & \\
\hline $\mathrm{H}$ & Hypertension & 高血圧 & 1 \\
\hline A & Age $\geqq 75 y$ & 年齢（75 歳以上） & 1 \\
\hline $\mathrm{D}$ & Diabetes mellitus & 糖尿病 & 1 \\
\hline $\mathrm{S}_{2}$ & Stroke/TIA & 脳卒中/TIA の既往 & 2 \\
\hline
\end{tabular}

文献 19 より引用改変

にワルファリンと DOACのメリットとデメリットを 示す. DOAC はワルファリンと比較して, 効果が同 等以上で, 頭蓋内出血の発生率が低く, 食事制限が なく，他の薬剤との相互作用が少ないことから，心 房細動患者の脳塞栓予防を新規に開始する際には, 可能な限りワルファリンよりも DOACを用いること が明記された（推奨クラス $\mathrm{I}$ )。表 4 に各 DOACの特 徵を示す. 服薬回数が 1 日 1 回と 2 回のものがあり, 減量基準がそれぞれ異なっていることに注意が必要 である。

\section{3）非弁膜症性心房細動患者に対するワルファリンは 年齢によらず，INR1.6〜2.6でコントロールする （血栓塞栓症の高リスク患者は除く）}

2013 年版ガイドラインにおいては, 非弁膜症性心 房細動患者に対するワルファリンを用いた抗凝固療 法の INR 管理目標は, 70 歳以上の高齢者が INR1.6 2.6, 70 歳未満の若年者が INR2.0〜3.0 とされてい た2).しかし, 実臨床においては若年者においても INR1.6〜2.6で管理される傾向があった. J-RHYTHM
レジストリーにおいて約 8,000 人の心房細動患者を 対象に至適 INRの解析が行われ, 高齢者と若年者の 区別なく, INR1.6〜2.6が塞栓症と大出血を最小限と する至適治療域であることが確認された ${ }^{6-8)}$. この結 果を踏まえて, 脳梗塞既往のない一次予防かつそれ ほど高リスクでない（ $\mathrm{CHADS}_{2}$ スコア $\leqq 2$ 点）患者 に対するワルファリン療法は, 年齢に関係なく INR1.6〜2.6での管理が推奨に変更された. 一方, 脳 梗塞既往を有する二次予防の患者やリスクの高い患 者 $\left(\mathrm{CHADS}_{2}\right.$ スコア $\geqq 3$ 点や担癌患者など）におい ては, 従来と同様に 70 歳未満の患者の場合は INR2.0 〜3.0, そして 70 歳以上の高齢者の場合は INR1.6 2.6 での管理が推奨とされた。

\section{4） $\mathrm{CHADS}_{2}$ スコア因子以外に考慮すべきその他の 危険因子}

2013 年版ガイドラインでは ${ }^{2)}$, 抗凝固療法施行の 際に考慮可能な「その他の危険因子」として, 心筋 症, 年齢 $(65 \sim 74$ 歳), および血管疾患 (心筋梗塞 の既往, 大動脈プラーク, 末梢動脈疾患) が挙げら れていた。今回のガイドラインでは ${ }^{1)}$, 上記の危険 因子に加えて, 本邦のレジストリー研究 (Fushimi AF Registry, J-RHYTHM Registry) ${ }^{9-11)}$ によって明ら かにされた持続性・永続性心房細動, 低体重（ミ $50 \mathrm{~kg}$ ), 腎機能障害, および左房径 $(>45 \mathrm{~mm})^{12)}$ が新たに加えられた。 そして, これらの「その他の 危険因子」を用いた心原性塞栓症のリスク評価は, $\mathrm{CHADS}_{2}$ スコアでカバーできないリスクを補うもの となっている.

表 3 ワルファリンと DOACのメリットおよびデメリット

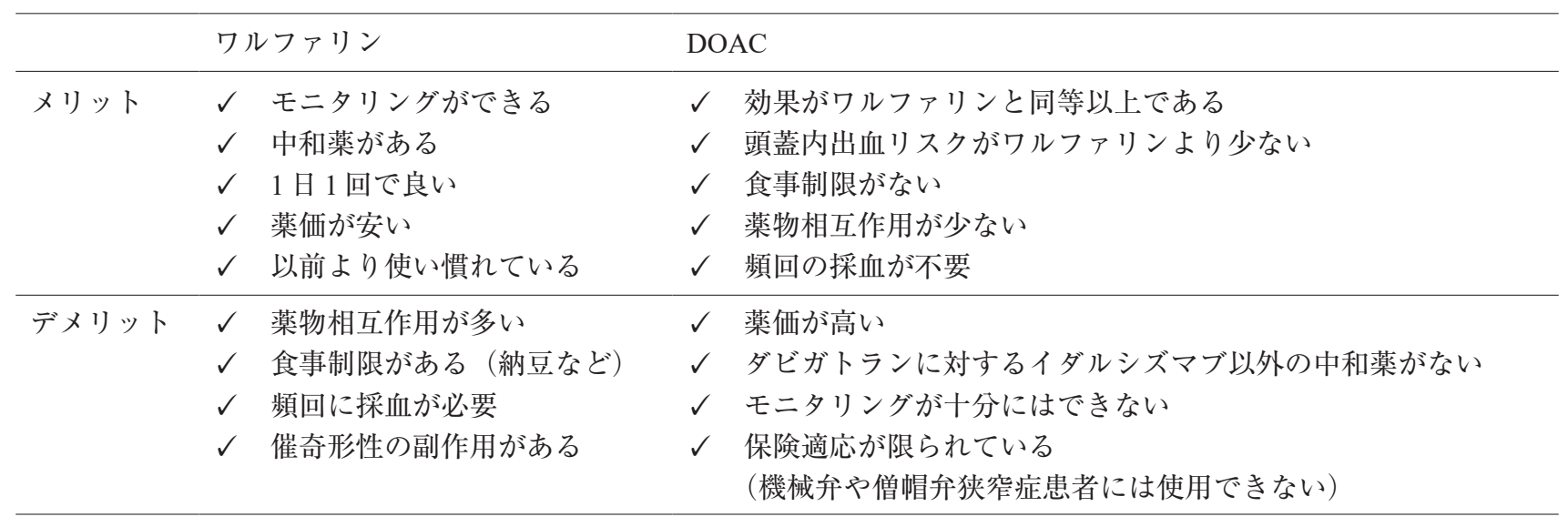


表 4 各DOAC の用法・用量

\begin{tabular}{|c|c|c|c|c|}
\hline 分類 & 直接トロンビン阻害薬 & Xa 因子阻害薬 & & \\
\hline 一般名 & ダビガトラン & リバーロキサバン & アピキサバン & エドキサバン \\
\hline 商品名 & プラザキサ & イグザレルト & エリキュース & リクシアナ \\
\hline \multirow[t]{2}{*}{ 効能 - 効果 } & \multicolumn{4}{|c|}{ 非弁膜症性心房細動患者における虚血性脳卒中および全身性塞栓症の発症抑制 } \\
\hline & - & \multicolumn{3}{|c|}{ 静脈血栓塞栓症の治療・再発抑制 } \\
\hline 服薬回数 & 1 日 2 回 & 1 日 1 回 & 1 日 2 回 & 1 日 1 回 \\
\hline 通常 1 回量 & $150 \mathrm{mg}$ & $15 \mathrm{mg}$ & $5 \mathrm{mg}$ & $60 \mathrm{mg}$ \\
\hline 減量 1 回量 & $110 \mathrm{mg}$ & $10 \mathrm{mg}$ & $2.5 \mathrm{mg}$ & $30 \mathrm{mg}$ \\
\hline $\begin{array}{l}\text { 減量基準（ダビ } \\
\text { ガトランは減量 } \\
\text { 考慮基準） }\end{array}$ & $\begin{array}{ll}\checkmark & \mathrm{Ccr}<50 \mathrm{~mL} / \mathrm{min} \\
\checkmark & \mathrm{P} \text { 糖蛋白阻害剤併用 } \\
\checkmark & 70 \text { 歳以上 } \\
\checkmark & \text { 消化管出血既往 }\end{array}$ & $\checkmark \mathrm{Ccr}<50 \mathrm{~mL} / \mathrm{min}$ & $\begin{array}{l}\checkmark \text { 以下の } 2 \text { つ以上に該当 } \\
\cdot 80 \text { 歳以上 } \\
\quad \cdot \text { 体重 } 60 \mathrm{~kg} \text { 以下 } \\
\cdot \text { 血清 } \mathrm{Cr} \geqq 1.5 \mathrm{mg} / \mathrm{dL}\end{array}$ & $\begin{array}{l}\checkmark \text { 以下のいずれかに該当 } \\
\cdot \text { C } \mathrm{Cr}<50 \mathrm{~mL} / \mathrm{min} \\
\cdot \mathrm{P} \text { 糖蛋白阻害剤併用 } \\
\cdot \text { 体重 } 60 \mathrm{~kg} \text { 以下 }\end{array}$ \\
\hline
\end{tabular}

\section{2. 周術期の抗凝固療法における変更点}

\section{1）リスク手技別の抗凝固療法}

抜歯や内視鏡処置時にワルファリンを中止した際 に，脳梗塞および脳卒中を約 $1 \%$ 発症することが報 告されている ${ }^{13,14)}$. このことから, 歯科手術, 通常 の消化管内視鏡検査, 白内障手術，および体表面の 手術については出血低リスク手技として, 抗凝固薬 を原則継続すべきとされた（推奨クラス I）。さら に, 内視鏡的粘膜生検, 経尿道的手術, 緑内障や硝 子体の手術, 心臓デバイス植込み手術などは出血中 リスク手技として, 抗凝固薬を可能な限り内服継続 すべきとされた（推奨クラス IIa）。一方，ポリペク トミー, 内視鏡下粘膜下層剝離術 (ESD), 経皮的ラ ジオ波焼灼術, 肝生検, 腎生検などは出血高リスク 手技として, 抗凝固薬を可能な限り休薬すべきとさ れた（推奨クラス IIa）。このうち, 出血高リスクの 消化器内視鏡手技（ポリペクトミー, 内視鏡下粘膜 下層剥離術など）の DOAC 休薬については，当日朝 休薬して翌日朝から再開すべきとされた（推奨クラ ス IIa).

\section{2) 抗凝固薬休薬時のヘパリン置換は推奨されない}

これまで明らかなエビデンスがないにも関わらず, 外科手術に際してはワルファリンを休薬してへパリ ン置換することが経験的に行われていた。しかし， 手術に際してへパリン置換を行う群と行わない群で
比較したところ (BRIDGE 試験) ${ }^{15}$, 血栓塞栓症の発 症率には差がなく, 大出血発症率はへパリン置換群 の方が有意に多かった，また，DOACにおいても同 様の結果であった ${ }^{16)}$ 。このことを踏まえて, ワル ファリンおよび DOAC の休薬を要する出血高リスク の外科的手術 - 処置の際には, ヘパリン置換は不要 とされた（推奨クラス IIb）。一方, 僧帽弁狭窄症や 機械弁置換術後および血栓塞栓症リスクが非常に高 い患者（3力月以内の脳梗塞の既往がある， $\mathrm{CHADS}_{2} \geqq 4$ 点など）においてはワルファリン休薬時 のヘパリン置換は考慮すべきとされ, DOACの場合 はへパリン置換を考慮してもよいとされた。

\section{3. 虚血性心疾患を合併した心房細動患者に対す る抗血栓療法における変更点}

心房細動患者における虚血性心疾患の合併は 8〜 $15 \%$ と比較的高く, 実臨床においてしばしば遭遇す る. 経皮的冠動脈インターベンション（PCI）患者 には低用量アスピリンと P2Y12 受容体拮抗薬の併用 療法が一般に行われる。そのため, 心房細動患者が 急性心筋梗塞を発症した場合は, 抗凝固薬にこれら 2 種類の抗血小板薬を加えた 3 郕併用療法が行われ るが, 出血リスクの増大が危惧される. 2013 年に公 表されたWOEST 試験 ${ }^{17)}$ では, PCI 施行患者で心房 細動に対して抗凝固療法が必要な患者において，ワ 


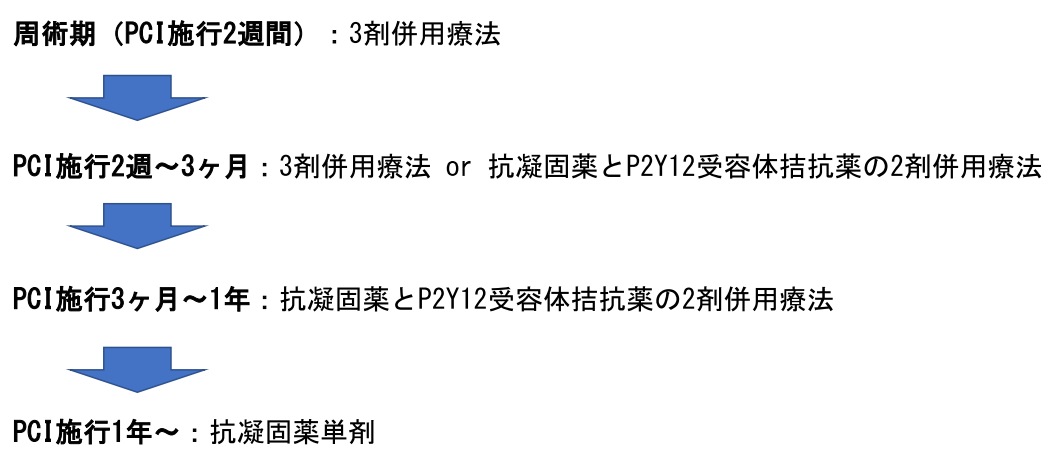

図 1 PCI 術後の心房細動患者に対する抗凝固薬と抗血小板薬の標準的な使い方（ガイドラインを参考に筆者が作成）

ルファリン+クロピドグレルの 2 剂併用療法は 3 剤併 用療法と比較して, 血栓症を増加させずに出血性イ ベントを減少させた。さらに, 最近本邦で行われた AFIRE 試験 ${ }^{18)}$ においては, PCIを施行して 1 年以降 (慢性期) の心房細動患者に対して, リバーロキサバ ン単郕がリバーロキサバン+抗血小板薬単剤の 2 鼡併 用療法に比較して, 出血イベントおよび虚血イベン トともに有意に減少させた。これらの報告を踏まえ て，心房細動患者に対して PCI を施行する際の推奨 する抗血栓療法の薬剤選択および投与期間が作成さ れた。周術期（2 週間以内）は 3 剂併用療法とする が, その後は血栓リスクと出血リスクのバランスを 評価したうえで標準治療として周術期（2 週間）以 降にアスピリンを中止し, 抗凝固薬と P2Y12 受容体 拮抗薬の 2 郕併用療法にすることが推奨されている. ただし，血栓リスクがきわめて高いと判断された患 者に限っては, 3 郕併用療法を医師の裁量で 1 ～ 3 力 月まで延長可能とした。 そして， 1 年以上経過した 際には, P2Y12 受容体拮抗薬も中止して抗凝固薬単 凨にすることを標準治療とし, 血栓リスクの高い患 者は, 12 力月以上の $\mathrm{OAC}$ とアスピリンあるいは P2Y12 受容体拮抗薬の 2 剂併用療法の継続を考慮す る, と記された（詳細については，2020 年改訂版不 整脈薬物治療ガイドラインを参照 https://www.jcirc.or.jp/guideline/guideline-series/). このガイドライ ンを参考にして, 筆者は PCI術後の心房細動患者に 対する抗凝固薬と抗血小板薬の標準的な使い方を 罒1のようにしている.

\section{4. 出血時の対応における変更点}

\section{1）DOAC 内服における出血時の対応}

2013 年版ガイドラインでは, ワルファリン内服に おける出血時の対応については記載されていたが, DOACについては, ダビガトラバンの中和薬である イダルシズマブ（2016年に保険承認）がまだ使用で きなかったこともあって記載されていなかった。今 回のガイドラインでは, DOAC 内服における出血時 の対応が明記された。軽度では「経過観察, DOAC1 回もしくは 1 日分休薬」, 中等度から重度では「休 薬, 活性炭投与, 止血, 輸液, 十分な降圧, 中和 (ダ ビガトランに対するイダルシズマブ)」となってい る。ただし，たとえ軽度であっても重要臓器（脳や 眼底など）の出血では, 中等度から重度に準じて対 応を考慮する。

\section{2）ワルファリンおよび DOAC の中和に関して}

ワルファリンの中和には，プロトロンビン複合体 製剂，新鮮凍結血漿，ビタミン $\mathrm{K}$ の投与が行われ る. 急速是正にはプロトロンビン複合体製剂とビタ ミン $\mathrm{K}$ の併用投与が勧められる。一方, DOACにつ いては, ダビガトランではイダルシズマブ, Xa 阻害 薬では andexanet alfa（2020 年 6 月現在未承認），お よび全ての DOACに対してはプロトロンビン複合体 製剤／遺伝子組換え第 VII 因子製剤（いずれも保険 適用外）を用いる.

\section{5. まとめ}

2020 年 3 月に発表された不整脈薬物治療ガイドラ 
インは，2013 年版ガイドライン以降に新たに報告さ れたエビデンスをもとに改訂が行われた。本稿では 心房細動に対する抗凝固療法についての変更点を中 心に述べた．社会の高齢化に伴って本邦の心房細動 患者数は年々増加しており, 実臨床において高頻度 に遭遇する疾患である。そして，ワルファリンや DOAC といった抗凝固薬は心房細動に伴う脳塞栓症 の発症予防には不可欠な薬剤である。しかし，これ らの抗凝固薬は脳出血を含めた出血イベントを起こ しやすい薬物であり，エビデンスに基づいた適切な 薬片選択およびリスク管理が必要とされる。今回改 訂されたガイドラインを，安全で効果的な抗凝固療 法実践の一助にしていただければ幸いである。

\section{著者全員の利益相反（COI）の開示：} 高橋尚彦：講演料・原稿料など（第一三共, バイエ ル薬品, ブリストルマイヤーズ，日本ベーリンガー インゲルハイム, トーアエイヨー, ファイザー)，臨 床研究 (治験) (第一三共), 研究費 (受託研究, 共 同研究，寄付金等）（小野薬品）

篠原徹二 : 本論文発表内容に関連して開示すべき企 業等との利益相反なし

\section{文献}

1) 日本循環器学会/日本不整脈心電学会合同ガイドライ ン：2020 年改訂版 不整脈薬物治療ガイドライン

2) 循環器病の診断と治療に関するガイドライン (2012 年度 合同研究班報告) : 心房細動治療 (薬物) ガイドライン (2013 年改訂版).

3) Durães AR, de Souza Roriz P, de Almeida Nunes B, Albuquerque FP, de Bulhões FV, de Souza Fernandes AM, Aras R: Dabigatran versus warfarin after bioprosthesis valve replacement for the management of atrial fibrillation postoperatively: DAWA Pilot Study. Drugs R D 16: 149-154, 2016.

4) Yadlapati A, Groh C, Malaisrie SC, Gajjar M, Kruse J, Meyers S, Passman R: Efficacy and safety of novel oral anticoagulants in patients with bioprosthetic valves. Clin Res Cardiol 105: 268-272, 2016.

5) Suzuki S, Yamashita T, Okumura K, Atarashi H, Akao M, Ogawa H, Inoue H: Incidence of ischemic stroke in Japanese patients with atrial fibrillation not receiving anticoagulation therapy - pooled analysis of the Shinken Database, JRHYTHM Registry, and Fushimi AF Registry. Circ J 79: $432-438,2015$.

6) Inoue H, Okumura K, Atarashi H, Yamashita T, Origasa H, Kumagai N, Sakurai M, Kawamura Y, Kubota I, Matsumoto K, Kaneko Y, Ogawa S, Aizawa Y, Chinushi M, Kodama I,
Watanabe E, Koretsune Y, Okuyama Y, Shimizu A, Igawa O, Bando S, Fukatani M, Saikawa T, Chishaki A; J-RHYTHM Registry Investigators: Target international normalized ratio values for preventing thromboembolic and hemorrhagic events in Japanese patients with non-valvular atrial fibrillation: Results of the J-RHYTHM Registry. Circ J 77: 2264-2270, 2013.

7) Yamashita $T$, Inoue $H$, Okumura $K$, Atarashi $H$, Origasa $H$; J-RHYTHM Registry Investigators: Warfarin anticoagulation intensity in Japanese nonvalvular atrial fibrillation patients: A J-RHYTHM Registry analysis. J Cardiol 65: 175-177, 2015.

8) Kodani E, Atarashi H, Inoue H, Okumura K, Yamashita T; J-RHYTHM Registry Investigators: Target intensity of anticoagulation with warfarin in Japanese patients with valvular atrial fibrillation-subanalysis of the J-RHYTHM Registry. Circ J 79: 325-330, 2015.

9) Takabayashi K, Hamatani Y, Yamashita Y, Takagi D, Unoki T, Ishii M, Iguchi M, Masunaga N, Ogawa H, Esato M, Chun YH, Tsuji H, Wada H, Hasegawa K, Abe M, Lip GY, Akao M: Incidence of stroke or systemic embolism in paroxysmal versus sustained atrial fibrillation: The Fushimi Atrial Fibrillation Registry. Stroke 46: 3354-3361, 2015.

10) Hamatani $Y$, Ogawa H, Uozumi R, Iguchi $M$, Yamashita $Y$, Esato M, Chun YH, Tsuji H, Wada H, Hasegawa K, Abe M, Morita S, Akao M: Low body weight is associated with the incidence of stroke in atrial fibrillation patients - insight from the Fushimi AF Registry. Circ J 79: 1009-1017, 2015.

11) Kodani $\mathrm{E}$, Atarashi $H$, Inoue $H$, Okumura $K$, Yamashita $T$, Origasa H; J-RHYTHM Registry Investigators: Impact of creatinine clearance on outcomes in patients with nonvalvular atrial fibrillation: A subanalysis of the J-RHYTHM Registry. Eur Heart J Qual Care Clin Outcomes 4: 59-68, 2018.

12) Hamatani Y, Ogawa H, Takabayashi K, Yamashita Y, Takagi D, Esato M, Chun YH, Tsuji H, Wada H, Hasegawa K, Abe M, Lip GY, Akao M: Left atrial enlargement is an independent predictor of stroke and systemic embolism in patients with non-valvular atrial fibrillation. Sci Rep 6: 31042 , 2016

13) Wahl MJ: Dental surgery in anticoagulated patients. Arch Intern Med 158: 1610-1616, 1998 .

14) Blacker DJ, Wijdicks EF, McClelland RL: Stroke risk in anticoagulated patients with atrial fibrillation undergoing endoscopy. Neurology 61: 964-968, 2003.

15) Douketis JD, Spyropoulos AC, Kaatz S, Becker RC, Caprini JA, Dunn AS, Garcia DA, Jacobson A, Jaffer AK, Kong DF, Schulman S, Turpie AG, Hasselblad V, Ortel TL; BRIDGE Investigators: Perioperative bridging anticoagulation in patients with atrial fibrillation. N Engl J Med 373: 823-833, 2015.

16) Douketis JD, Healey JS, Brueckmann M, Eikelboom JW, Ezekowitz MD, Fraessdorf M, Noack H, Oldgren J, Reilly P, Spyropoulos AC, Wallentin L, Connolly SJ: Perioperative bridging anticoagulation during dabigatran or warfarin interruption among patients who had an elective surgery or procedure. Substudy of the RE-LY trial. Thromb Haemost 113: 625-632, 2015. 
17) Dewilde WJ, Oirbans T, Verheugt FW, Kelder JC, De Smet BJ, Herrman JP, Adriaenssens T, Vrolix M, Heestermans AA, Vis MM, Tijsen JG, van't Hof AW, ten Berg JM; WOEST study investigators: Use of clopidogrel with or without aspirin in patients taking oral anticoagulant therapy and undergoing percutaneous coronary intervention: An open-label, randomised, controlled trial. Lancet 381: 1107-1115, 2013.

18) Yasuda S, Kaikita K, Akao M, Ako J, Matoba T, Nakamura
M, Miyauchi K, Hagiwara N, Kimura K, Hirayama A, Matsui $\mathrm{K}$, Ogawa H; AFIRE Investigators: Antithrombotic therapy for atrial fibrillation with stable coronary disease. N Engl J Med 381: 1103-1113, 2019.

19) Gage BF, Waterman AD, Shannon W, Boechler M, Rich MW, Radford MJ: Validation of clinical classification schemes for predicting stroke: Results from the National Registry of Atrial Fibrillation. JAMA 285: 2864-2870. 2001. 